\title{
Analyze Female Entrepreneurship: Evidence from Greece
}

\author{
Irene Fafaliou $^{1}$, Ioannis Salamouris ${ }^{2}$
}

\begin{abstract}
:
The aim of this paper is to identify the profile of existing female entrepreneurs in Greece, highlight their main characteristics, and interpret their beliefs in relation to their entrepreneurial and personal life. To this end we conducted an on-line national questionnaire survey from November 2012 to January 2013, using a sample of 300 women entrepreneurs. The main findings indicate that the majority of the participants feel strong, successful, proud and well respected due to practicing entrepreneurship. However, despite their great potential in becoming successful entrepreneurs, they also reported fears related to the entrepreneurial reality. Further, most of them expressed guilty feelings for the limited time they devote to their families. Also, almost half of them stated that entrepreneurship has no gender thus implying that the debate on women's entrepreneurship is outdated. $70 \%$ of the sample stated that economic crisis will bring out more women entrepreneurs despite the realized risks associated with new business ventures. Finally, the limitations of this work and policy implications are discussed.
\end{abstract}

Key Words: Women Entrepreneurship, Characteristics, Attitudes, Performance, Family and Working Life, Greece

JEL Classification: J16, J21, J22, J82

\footnotetext{
${ }^{1}$ University of Piraeus, Department of Economics, 80 Karaoli \& Dimitriou Street, 18534 Piraeus, Tel.: +30210 4142157, e-mail::fafaliou@unipi.gr

${ }^{2}$ Hellenic American University, Athens Campus, 12 Kaplanon Street, 10680 Athens, Tel: +30210 3680084,e-mail: isalamouris@hauniv.edu
} 


\section{Introduction}

Entrepreneurship and economic growth are closely related. Smith (2010) suggests that the level of entrepreneurial activity in any country has a substantial positive effect on the level of the economic growth in that country. Traditionally, a subconscious belief dictated that entrepreneurship was associated with males rather than females, therefore entrepreneurship in the past had never issues regarding gender differences like other concerns in life. In the last fifteen years a significant number of women broke out of their traditional role and their corporate careers and embraced entrepreneurship.

The increasing interest in entrepreneurship in general triggered an interest on women's entrepreneurship (Boyd, 2005; Brush et al., 2006; Pines et al., 2010). Female entrepreneurs have been nominated as the new power for growth of the economies in developing countries. As Minniti and Naudé (2010) suggest, a number of stakeholders describe women as an important "untapped source" of economic growth and development. The significant increase on the proportion of women undertaking entrepreneurship has pinched the attention of both academics and nonacademics. A large volume of research was made in concepts referring to differences between women and men entrepreneurs trying to identify a gender gap in entrepreneurship (Marlow and Patto, 2005; Jamali, 2009; Pines et al., 2010). In this paper we attempt to distance our research from the gender gap approach, although somehow has been addressed, and focus on identifying, and recording the perceptions, practices and approaches that the female entrepreneurs exhibit towards both their professional and personal life. In addition, an attempt in profiling female entrepreneurs was made by gathering information related to the image of women entrepreneurs on their daily, professional, social, and personal reality in Greece.

The paper is organized as follows. Section two presents a literature review on female entrepreneurship in the last decade worldwide and specifically in Greece, and comments on the findings. Section three describes the research design of the pear including information in reference to the sample, questionnaire and the data description. Section four reports the findings of our research and provides comparisons to previous research. Section five discusses the contribution of our findings on women entrepreneurship and demonstrates gaps and implications for further research.

\section{Literature Review}

Entrepreneurship has become a popular research topic because it has been acknowledged that the economic growth is positively related to entrepreneurial activity (Smith, 2010). More specifically, a high interest was developed in order to 
understand female entrepreneurial activity. The reason to that is the key role women play in entrepreneurship all over the world, as well as the evidence that women face different difficulties in starting and operating a business in comparison to men. In early ' 90 s the majority of research referring on entrepreneurship made no gender distinctions. In other words even if female entrepreneurs existed in a study, no interest was expressed in identifying or understanding their gender characteristics in relation to entrepreneurship (Loza, 2011).

Globally, women represent more than one third of all people involved in entrepreneurial activity (Minniti et al., 2005). Evidently, women play a crucial role in the expansion of entrepreneurship (Jalbert, 2000; Minniti et al., 2005). Nevertheless, the findings show that a gap between men and women still exists in the level of desire, motivation and tendency to become entrepreneurs (Minniti and Nardone, 2007). Initially, the research on women entrepreneurs was targeted on understanding their background and the organizational characteristics of their businesses (Avolio and Radović-Marković, 2013).

It has been observed that there is a differentiation between the factors that influence men and women in the creation of new businesses. More specifically women faced different challenges in terms of family, social support, access to funding et alia (Radović-Marković, 2006). The existence of differences has created limitations and restrictions, therefore women entrepreneurs attempt to adjust towards those limitations and restrictions. According to Radović-Marković (2009) the most dominant differences between male and female entrepreneurs are located to the following; women tend to start up a business in order to accomplish flexibility and independence. The feeling of personal satisfaction and advancement dominates their choice to become entrepreneurs. In the same spirit with the aforementioned, women motivate themselves to enter entrepreneurship due to distress and dissatisfaction with their current status. Finally, women follow their instinct more than men, whilst examining all possibilities before they decide to take an action, unlike men.

\subsection{The Greek Story}

According to the GEM 2011 survey Greece is ranked sixth among innovation economies with respect to women's participation in entrepreneurial activity. The findings of the GEM report revealed that the entrepreneurial action of female entrepreneurs was an outcome of the necessity motive rather than the opportunity incentive, in contrast to the respective male entrepreneurs. During the peak of the crisis in Greece an increase on the female early stage entrepreneurship is observed. The increasing unemployment which affects the female population more than the male one, drove females to get involved with entrepreneurship in order to make up for the loss income. 
An older research conducted by Sarri and Trihopoulou (2005) attempted a more detailed approach in the identifying factors that affect female entrepreneurship. The high level of bureaucracy and the lack of entrepreneurial incentive policies have affected both male and female entrepreneurs. Bureaucracy constitutes one of the major problems women face not only in starting-up their business, but in developing it too. Taking into consideration the economic environment and the social conditions, evidently create more barriers and obstacles for females to engage themselves in entrepreneurship. The access to funding and support through chamber associations or public authorities has been almost nonexistent; consequently the incentive to get involve in entrepreneurship abates.

\section{Research Design}

In this paper with respect to the findings of the existing research we attempt to approach female entrepreneurship from a different perspective. More specifically we are interested to highlight the female perception on entrepreneurship from existing female entrepreneurs rather than identifying reasons that prevent females to become entrepreneurs.

Women are one particularly understudied group of entrepreneurs, especially in Greece. The value of this study is its exploration of women entrepreneurs' motivations, backgrounds, and experiences. The data were collected in a period of two months started from November 2nd 2012 ending in January 2013. The survey range was Pan-Hellenic and the sample consisted of 300 participants. We have chosen a convenience sample approach due to the lack of a concentrated data base of exclusively female entrepreneurs in Greece. It is important to clarify that a lot of business in Greece appear to be owned by females but in reality are owned and managed by males. Therefore, in order to avoid such cases we handpicked business where not only the owner is a female but is also running the business, either as owner or partner.

The research is aiming to record female entrepreneurs' perceptions, practices and approaches towards both their professional and personal life. The survey questions focused on data collection offering not only a quantitative analysis and an approach to women entrepreneurship but mainly collecting qualitative facts leading to a specific image of women entrepreneurs' daily, professional, social and personal reality in Greece.

The survey was constructed up on the basis of an online questionnaire consisted of 32 questions. The questions were designed in such way as to facilitate the completion, not to be timely, but also to keep a high interest level of participants. The structure of the questionnaire was based into five sections including the demographics of our sample. The first set of questions records the demographic 
characteristic of our sample. The second set of questions aims on identifying the factors that affected female entrepreneurs to start up their own business. The third set is addressing issues and concerns regarding their feelings, fears and perceptions that occurred due to the undertaking of entrepreneurship. The fourth set of questions investigates how women realize the impact of entrepreneurship in their professional, social and family life. The final set of questions relates to perceptions around entrepreneurship in general and focuses on how women perceive entrepreneurship regardless of the gender of the entrepreneur. In addition, the participants were asked to identify the characteristics of a successful entrepreneur according to their opinion and highlight differences observed between male and female entrepreneurs. Our findings and their implications are presented in more detail in the following section.

\section{Findings}

\subsection{Demographics}

Almost seven out of ten women entrepreneurs belong to the age group 25-44 (see Table 1). Eight out of ten are holders of an undergraduate and graduate degree (see Table 2). $70 \%$ of the sample state that they started their business activity within the last decade and half of them during the last 3 years 2009-2012 (see Table 3 and Figure 1), the period with the highest recorded recession in the modern history of Greece. The majority of the female entrepreneurs are operating in the services sector (see Table 4) and 72\% of those businesses appear in Attica and Thessaloniki, the biggest urban centres in Greece (see Table 5). Summing up our findings, we conclude that female entrepreneurs are relative young with a high level of education. The most popular line of business is located in the services sector most preferably in the two biggest urban centres of Greece.

Table 1: Age of Women Entrepreneurs

\begin{tabular}{|c|c|}
\hline Age groups & Percentage \\
\hline $18-24$ & $1.3 \%$ \\
\hline $25-34$ & $34.3 \%$ \\
\hline $35-44$ & $34.0 \%$ \\
\hline $45-54$ & $21.3 \%$ \\
\hline $55+$ & $9.0 \%$ \\
\hline
\end{tabular}


Table 2: Level of Education of Women Entrepreneurs

\begin{tabular}{|c|c|}
\hline Level & Percentage \\
\hline High School & $18 \%$ \\
\hline Undergraduate degree & $41 \%$ \\
\hline Graduate degree & $41 \%$ \\
\hline
\end{tabular}

Table 3: When Women Entrepreneurs started their Business Activities

\begin{tabular}{|c|c|}
\hline Period & Percentage \\
\hline Till 1999 & $29.0 \%$ \\
\hline $2000-2008$ & $36.0 \%$ \\
\hline $2009-2012$ & $35 \%$ \\
\hline
\end{tabular}

Figure 1: When Women Entrepreneurs started their Business Activities

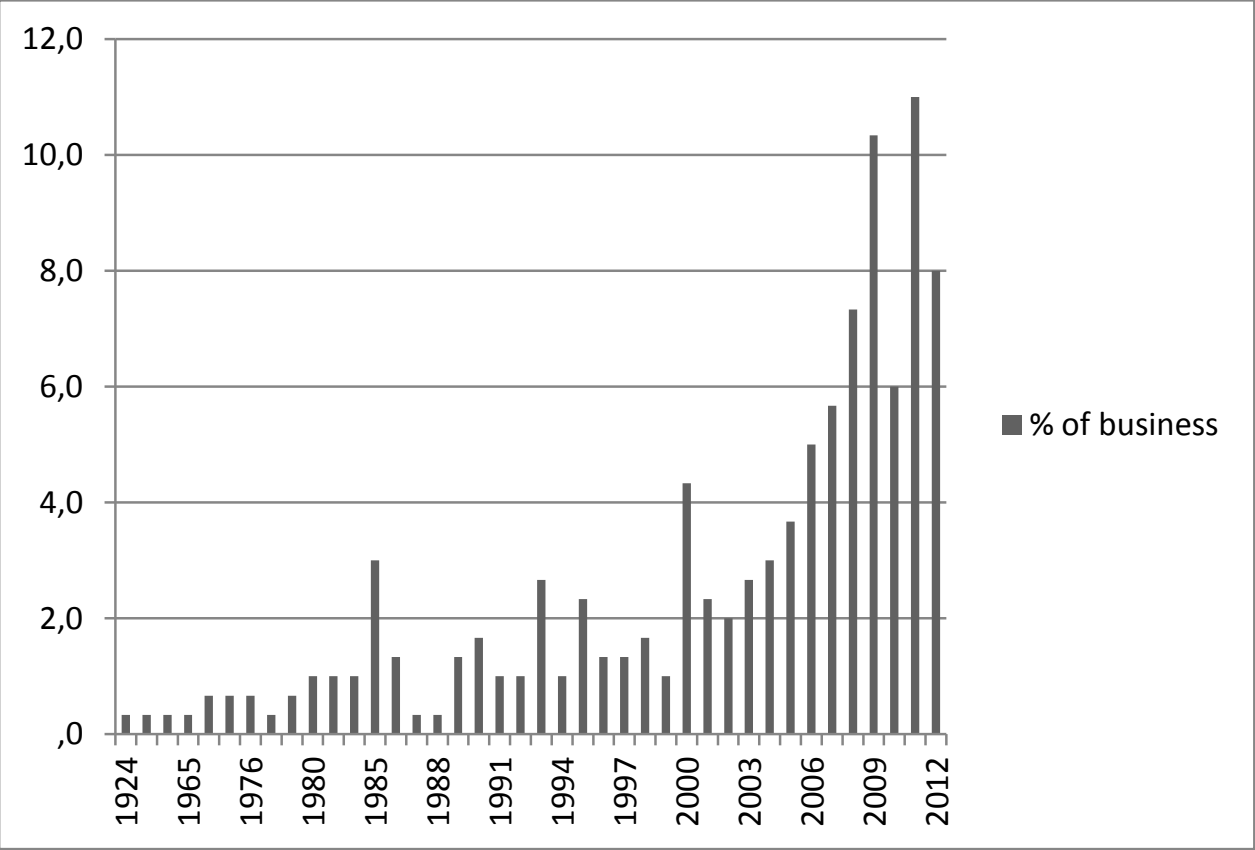


Table 4: Sectors in which Women Entrepreneurs Operate

\begin{tabular}{|c|c|}
\hline Sector & Percentage \\
\hline Industry & $10.0 \%$ \\
\hline Services & $68.0 \%$ \\
\hline Wholesale & $22.0 \%$ \\
\hline
\end{tabular}

Table 5: Geographic Location of Women Entrepreneurs

\begin{tabular}{|c|c|}
\hline Area & Percentage \\
\hline Attica & $60.0 \%$ \\
\hline Thessaloniki & $12.0 \%$ \\
\hline Rest of Greece & $28.0 \%$ \\
\hline
\end{tabular}

\subsection{How They Started}

The majority of the female entrepreneurs, that is $80 \%$ of our sample, clearly declare that they are really pleased that they started their own business and if they could go back in time they would have done the same thing (see Figures 2 and 3 respectively).

Figure 2: "How satisfied are you from having your own business?"

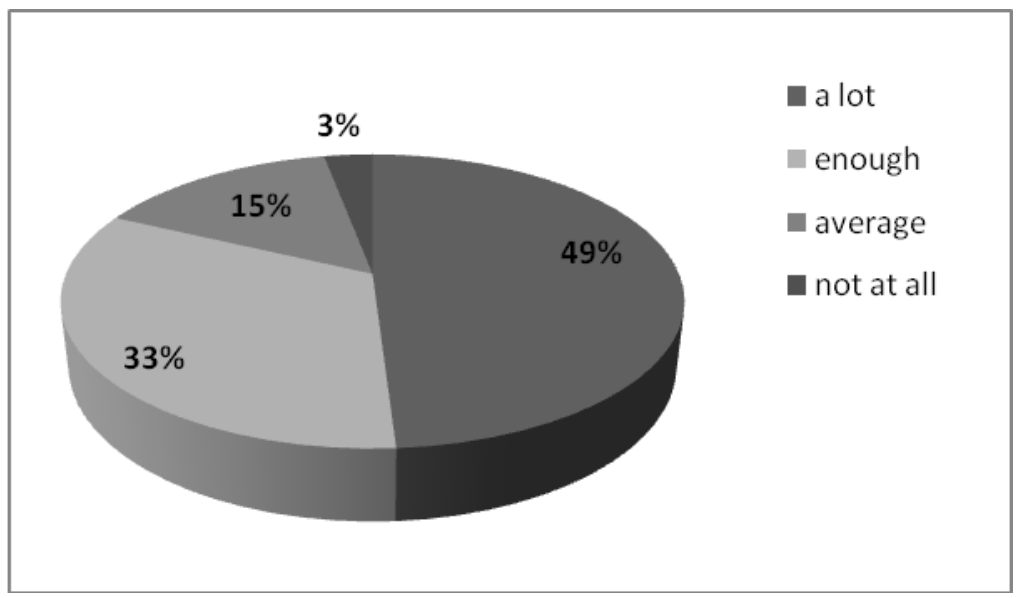


Figure 3: "If you could turn back in time, would you have made the same decision?"

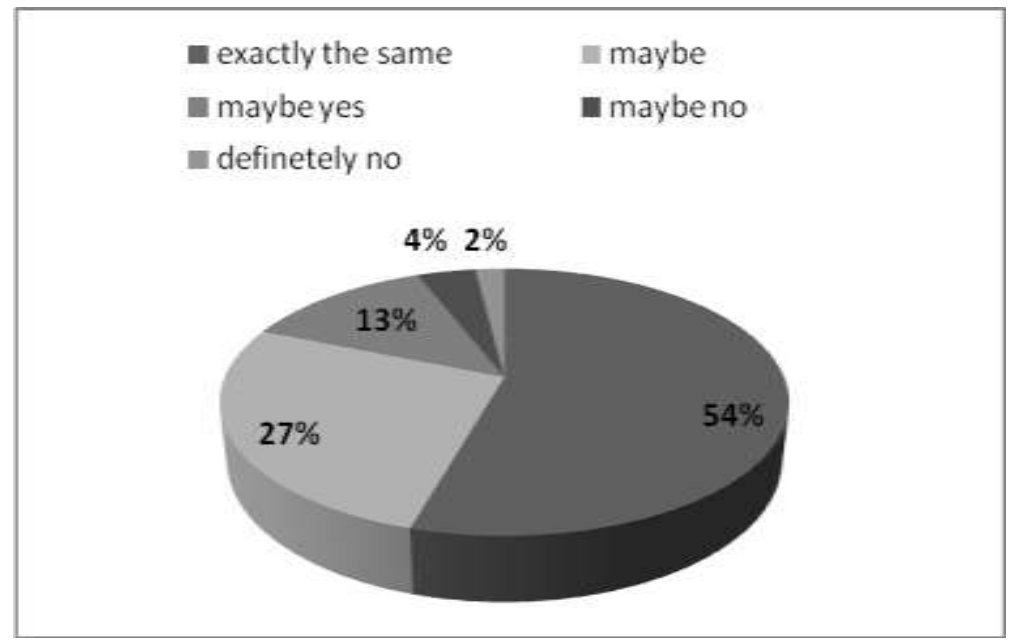

The age they started their entrepreneurial activity falls under and over the 25-34 age group (Figure 4).

Figure 4: Age of starting off versus age of women entrepreneurs

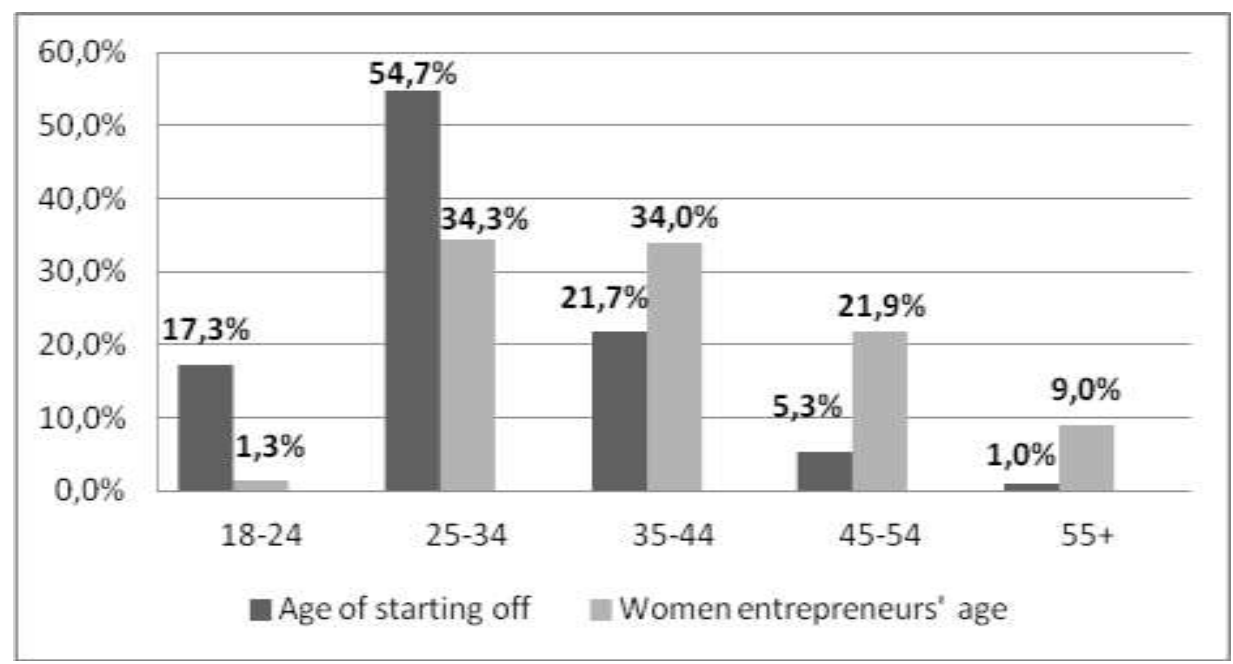

As shown in Figure 5, 31\% of our sample states that the choice to start up their own business was absolutely conscious and they have planned it very carefully. $66 \%$ of 
the female entrepreneurs declared that their decision was based on the conditions, necessity motive and opportunities.

Figure 5: "How did they start?"

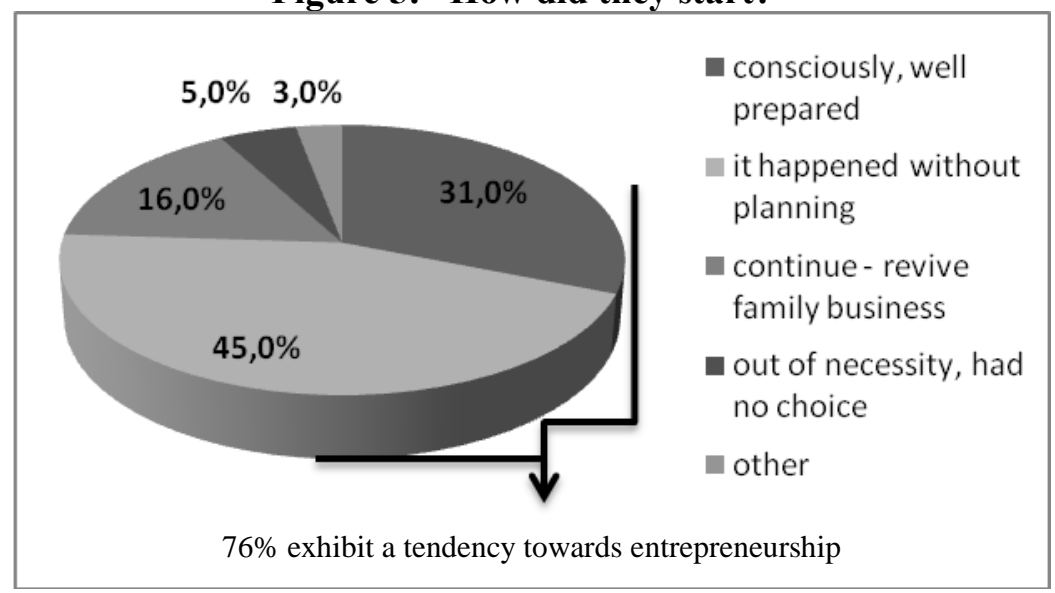

In addition, it was stated that their decision was not initiated by family entrepreneurial role models or by the family environment in general. They do say though that a family environment where entrepreneurship already exists may facilitate the decision but is not a decisive factor. The existence of a family business most of the times demotivates entrepreneurship especially when this business is in urban centres. It is observed that female entrepreneurs embrace their family business and their relatives as partners mostly in the rest of Greece. It appears female entrepreneurs face less restrictions from the family and social environment in urban centres than the rest of Greece.

\subsection{How Entrepreneurship Makes Them Feel}

In this section female entrepreneurs were asked to identify how entrepreneurship makes them feel in general. More specifically, they were asked to discuss possible comments and reactions coming from their family, business and social environment. In addition, they were asked to express their feelings towards the reaction of their environment and identify issues that may affect their everyday life (see Table 6).

Approximately $68 \%$ states that by just being an entrepreneur make them feel really successful regardless of the performance of their business. To a similar level they experience that they become more powerful because of their entrepreneurial activity $(75 \%)$. More than $60 \%$ of entrepreneurs states that receives commendatory comments because of their activity. They feel that they receive more respect from their environment due to their selection to become entrepreneurs. Family 
environment appears to be very supportive and embraces their entrepreneurial activities.

A very important finding is that although women do get support from their family still they feel guilty for not spending enough time with their loved ones. Cumulatively the percent of females feeling some guilt exceeds $60 \%$ and a $37 \%$ declares they experience no guilt. Although only $12.7 \%$ feel that family discourages entrepreneurial activity; the percentage of guilt appears to be inexcusable high (more than 60\%). Our explanation is that motherhood is very important for female entrepreneurs even if it is not questioned by their family. Finally, women feel that they must prove themselves even more intensely only just because they are entrepreneurs.

Table 6: How does entrepreneurship make women entrepreneurs feel?

\begin{tabular}{|l|c|c|c|}
\hline How often do you feel & $\begin{array}{c}\text { A lot / } \\
\text { Very } \\
\text { often }\end{array}$ & Sometimes & $\begin{array}{c}\text { Rarely/ } \\
\text { Never }\end{array}$ \\
\hline $\begin{array}{l}\text { That you become more powerful due to } \\
\text { entrepreneurship? }\end{array}$ & $74.7 \%$ & $18.7 \%$ & $6.7 \%$ \\
\hline Successful because you are an entrepreneur? & $67.7 \%$ & $24.0 \%$ & $8.3 \%$ \\
\hline $\begin{array}{l}\text { They speak highly of you because you are an } \\
\text { entrepreneur? }\end{array}$ & $62.7 \%$ & $26.7 \%$ & $10.7 \%$ \\
\hline $\begin{array}{l}\text { Respected because you are an entrepreneur? } \\
\text { Embraced by your family and friends for your } \\
\text { entrepreneurial activity? }\end{array}$ & $60.7 \%$ & $25.0 \%$ & $14.3 \%$ \\
\hline $\begin{array}{l}\text { That you have to prove yourself just because } \\
\text { you are a female entrepreneur? }\end{array}$ & $54.7 \%$ & $20.7 \%$ & $24.7 \%$ \\
\hline $\begin{array}{l}\text { Guilty for not devoting enough time to your } \\
\text { family? }\end{array}$ & $35.7 \%$ & $27.3 \%$ & $37.0 \%$ \\
\hline
\end{tabular}




\subsection{Everyday Life}

In this section we asked female entrepreneurs to provide information regarding the time management on their everyday professional and personal life, and to express their feelings that follow their daily routine.

$50 \%$ declares that they work between 8 and 11 hours on a daily basis. This does not change during weekends or holidays (see Figure 6). 70\% says they cannot take out of their mind their business not even during their sleep.

\section{Figure 6: "How often do you work during the night and/or during the weekend?"}

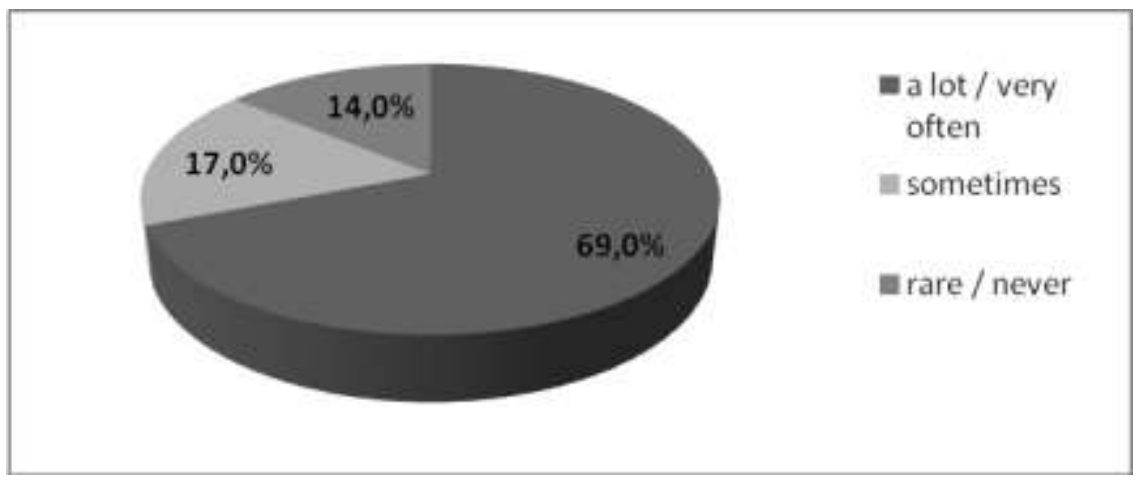

The personal time that female entrepreneurs have is limited to two hours a day and for $62 \%$ of the sample it does not even exceed the 2 hours on a daily basis. $18 \%$ emphatically stated that they hardly have any personal time or at all (see Figure 7).

Figure 7: "How much personal time do you have on a daily basis?"

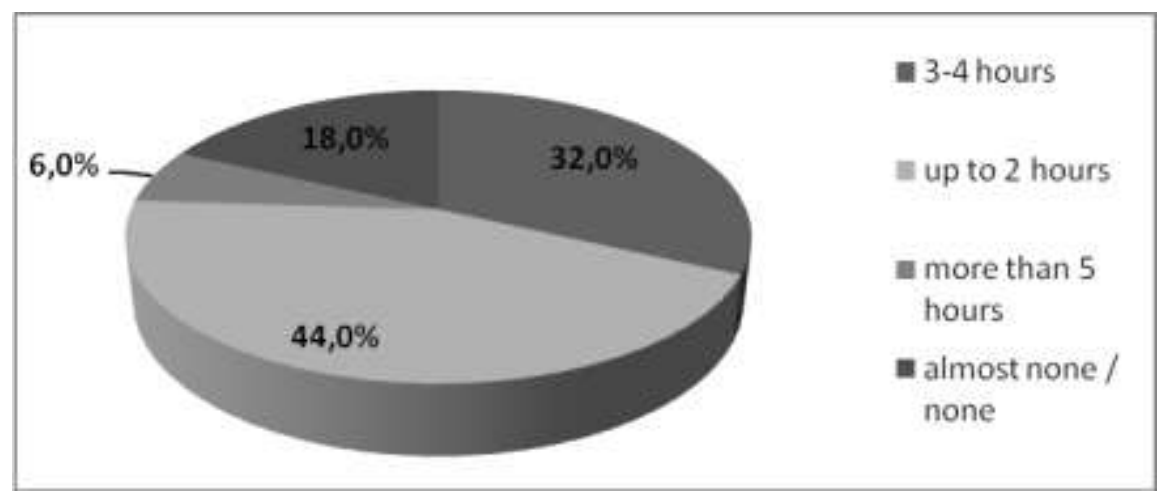


The majority expresses distress that relates to the economic environment in Greece and the future, nevertheless only $8 \%$ is thinking of abandoning their business (Figure 8).

Figure 8: "Have you ever thought of closing down your business?"

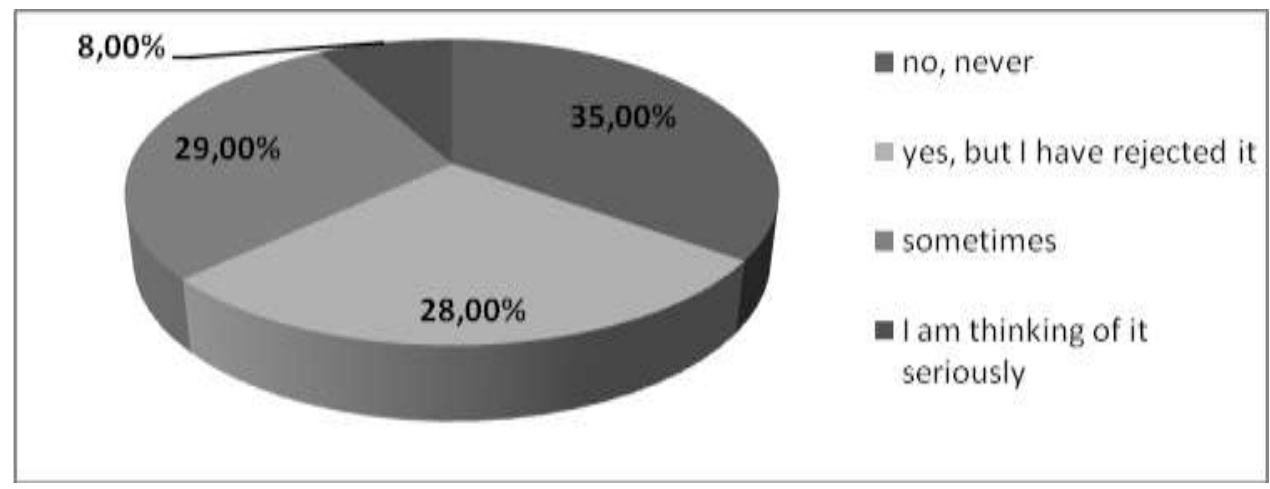

Female entrepreneurs appear to feel very strong about their decision to have their own business and even if the conditions are not ideal they have no intension to give up. A plausible explanation to that might be that satisfaction that occurs through entrepreneurship compensates their concerns and stress regarding the economic situation of the country.

\section{5 "Female Entrepreneurship" and "Success and Gender"}

In this section we put forward several questions attempting to identify if women believe that gender is related to success and how women entrepreneurs feel towards the term "female entrepreneurship". A large volume of the literature has been devoted to the gender effect on entrepreneurship (Pines et al., 2008; Jamali, 2009; Kobeissi, 2010), therefore, discovering what women think about the gender effect is very important. Women on a $50 \%$ basis feel proud in the sound of the term "female entrepreneurship", the remaining $50 \%$ are neutral. On the question if they think that the term "female entrepreneurship" is an outdated concept, 50\% agreed, the remaining claimed it is important. Women stated that there is a significant lack of policies and support on female entrepreneurship to a degree of $89 \%$ and $70 \%$ respectively. Women appear to be confident about their abilities however, emphatically stated that fear is their biggest suspension towards entrepreneurship (see Figure 9). 


\section{Figure 9: "Fear is your biggest suspension towards entrepreneurship."}

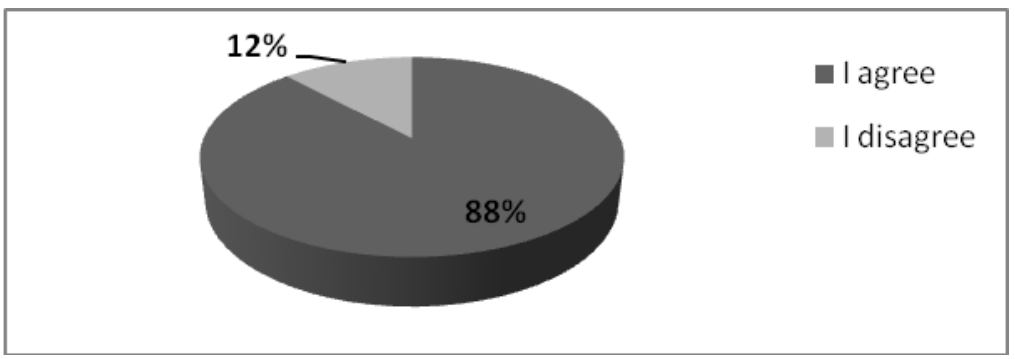

When women were asked to identify the characteristics for success in entrepreneurship in general and the characteristics that women should have, in order to succeed, no differences were entailed. In fact $80 \%$ agreed that the characteristics mentioned below are common for both genders (see Figure 10).

\section{Figure 10: "The characteristics for success in entrepreneurship are the same for men and women?"}

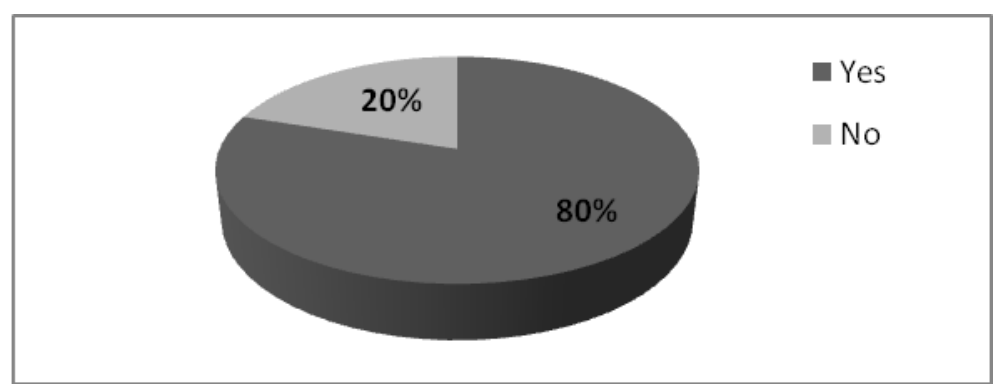

The top 5 characteristics for males and females were determination, vision, education, leadership and persistence (Figure 11). Therefore, being a successful entrepreneur is unrelated to their gender, rather is positively associated with the aforementioned qualities. Although no differences were spotted as far as success is concerned, female entrepreneurs do accept that in some tasks they are better than men and vice versa. 


\section{Figure 11: The 5 most important characteristics for success}

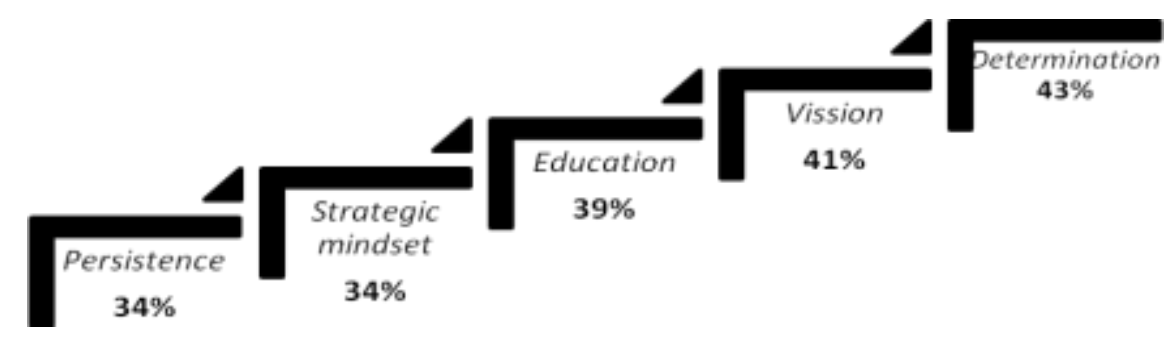

Although, women see entrepreneurship as a gender free concept, still they are looking forward for more support by the state in order to promote and facilitate female entrepreneurship.

Besides the above findings of our research several correlations were revealed between female entrepreneurship and environment, family and age. A key finding is that the desire towards entrepreneurship is positively correlated to the level of satisfaction that women experience from it. In others words, as long as entrepreneurship makes them feel strong, respectable and happy they will never abandon their business. $90 \%$, of women enjoy being entrepreneurs and only $10 \%$ states the opposite. This response is similar to all age groups and to all 3 business sectors and geographical locations.

Another finding that relates to the level of satisfaction is the way they started of their business. $31 \%$ stated that their choice was made consciously and it was not out of necessity. Only a 5\% clearly said that the selection was made out of necessity. $35 \%$ said that they had never thought of giving up their business, where a 57\% suggested that they have at least thought about it. Nevertheless, only $8 \%$ is seriously thinking of giving up their business.

A conscious decision and the level of satisfaction through entrepreneurship secure a high level of commitment on their business. On the contrary, necessity motives and dissatisfaction during their entrepreneurial life leads women to abort their business. Statistically, there is no significant correlation between satisfaction and sector or educational level or age or geographical orientation.

An interesting finding is that $51 \%$ of the respondents enjoys the term female entrepreneurship without necessary believing that entrepreneurship is not gender 
free. This response is correlated with the pride and satisfaction women enjoy by just being entrepreneurs.

\subsection{Contradictions}

In our analysis we spotted some contradictions on the responses in relation to the term "female entrepreneurship". 68\% suggests that there is no prejudice about female entrepreneurship and at the same time $90 \%$ believes that the social environment is not supporting sufficiently female entrepreneurs. If entrepreneurship is gender free why we should be looking for a special support on female entrepreneurship? Also, 58\% stated that they faced a problem in financing just because of their gender, where at the same time $50 \%$ responded that entrepreneurship is gender free. Apparently, though only 33\% sees it as gender free and believes that the lack of support on entrepreneurs is a common situation to both genders.

A major finding in our work is the sense of fear that women exhibit towards entrepreneurship. $88 \%$ acknowledges that fear is a dominant feeling when it comes to take an entrepreneurial action. Having in mind that all respondents are running a business, this response has a greater impact. If women entrepreneurs feel fear, imagine how the rest of the female population could be feeling about entrepreneurship. If fear is a dominant feeling on female entrepreneurs, then seeking for more support from professional bodies or the state does makes sense, regardless if entrepreneurship is gender free. The sense of fear was expressed in all age groups and to all levels of activity.

In conclusion, female entrepreneurs are aware of the business difficulties and consciously enter in the entrepreneurial world. Also, women place high value on their family role and do feel sometimes that they neglect their loved ones though their family environment is very supportive of their entrepreneurial activity. Finally when fear is surpassed, then they do enjoy very much entrepreneurship and become very committed to their business.

\section{Conclusion}

In the present paper, we approached female entrepreneurship in Greece through woman's perceptions. Unquestionably, the capacity of women entrepreneurs to contribute in the economy is no longer a matter of dispute, on the contrary has become a reality that must be taken into serious consideration. The difficulty in getting suitable jobs and desire for social recognition motivate them towards entrepreneurship. Female entrepreneurs clearly stated that being an entrepreneur is an activity that makes them feel proud about it. They enjoy the support of their social 
and family environment, but they never forget their role as mothers, wives or partners.

Because of the complexity of their role, they seek for more support from the state. Only fear stands between them and entrepreneurship; as soon as they overcome the fear, then entrepreneurship becomes normality. Female entrepreneurs state that entrepreneurship is gender free and in order to become a successful entrepreneur someone should possess specific qualities. The characteristics of their gender from time to time contribute in a different manner to entrepreneurship but not critically. Greek women entrepreneurs share also some important messages. The economic crisis will 'bring out / emerge' more women entrepreneurs. Determination, vision, education, leading qualifications, persistence, as well as communication abilities, patience, and responsibility are their allies in their entrepreneurship path.

This research, as any research work, has some limitations. Most of these are related to the size of our sample. Another issue is the lack of financial information about the business sectors involved or the income that the entrepreneurs make. Such information could have provided a greater understanding on the characteristics of female entrepreneurs and their perceptions. Future research could focus on a greater sample with more financial information. In addition, applying the same questionnaire on male entrepreneurs would provide more information about female entrepreneurship, allow for comparative analysis and identify if eventually entrepreneurship is gender free or not.

\section{References}

Avolio, A. B. and M. Radović-Marković (2013), "Women and Entrepreneurship: Female Durability, Persistence and Intuition at Work", Gower Publishing Limited and Ashgate, England.

Boyd, R.L. (2005), "Race, Gender, and Survival Entrepreneurship in Large Northern Cities during the Great Depression”, Journal of Socio-Economics, Vol. 34, pp. 331-339.

Brush, C., N. M. Carter, E. J. Gatewood, P. G. Greene and M. M. Hart (2006), "Women and Entrepreneurship", Contemporary Classics, Edward Elgar, Cheltenham.

Global Entrepreneurship Monitor (2012), "GEM 2011 Global Report”, Published online, http://www.gemconsortium.org

Global Entrepreneurship Monitor (2011), “The Women's Report 2010”, Published online, http://www.gemconsortium.org

Hisrich, R.D. (1990), “Entrepreneurship / Intrapreneurship”, American Psychologist, Vol. 45 Issue 2, pp. 209-222.

Jalbert, S. (2000), "Women Entrepreneurs in the Global Economy", Center for International Private Enterprise, Washington, DC.

Jamali, D. (2009), "Constraints and Opportunities Facing Women Entrepreneurs in Developing Countries: A Relational Perspective", Gender in Management: An International Journal, Vol. 24 Issue 4, pp. 232-251. 
Kobeissi, N. (2010), "Gender Factors and Female Entrepreneurship: International Evidence and Policy Implications", Journal of International Entrepreneurship, Vol. 8 Issue 1, pp. $1-35$.

Langowitz, N. and M. Minniti (2007), "The Entrepreneurial Propensity of Women", Entrepreneurship Theory \& Practice, Vol. 31 No. 3, pp. 341-364.

Lerner, M. and A. M. Pines (2011), "Gender and Culture in Family Business: a Ten-Nation Study", International Journal of Cross Cultural Management, Vol. 29, pp. 223-233.

Loza, E. (2011), "Female Entrepreneurship Theory: A Multidisciplinary Review of Resources", Journal of Women`s Entrepreneurship and Education, Vol. 1 Issue. 2, pp. 26-46.

Marlow, S. and D. Patton (2005), "All Credit to Men? Entrepreneurship, Finance and Gender", Entrepreneurship Theory \& Practice, Vol. 29 No. 6, pp. 717-735.

Minniti, M. (2010), "Female Entrepreneurship and Economic Activity", European Journal of Development Research, Vol. 22, pp. 294-312.

Minniti, M., P. Arenius and N. Langowitz (2005), "Global Entrepreneurship Monitor 2004 Report on Women and Entrepreneurship", Babson College: the Centre for Women's Leadership and London Business School

Minniti, M. and C. Nardone (2007), "Being in someone else's Shoes: The Role of Gender in Nascent Entrepreneurship", Small Business Economics, Vol. 28, pp. 223-39.

Minniti, M. and W. A. Naudé (2010), "What Do We Know About The Patterns and Determinants of Female Entrepreneurship Across Countries?", European Journal of Development Research, Vol. 13, pp. 1-17.

Pines, A. M., M. Lerner and D. Schwartz (2010), "Gender Differences in Entrepreneurship: Equality, Diversity and Inclusion in Times of Global Crisis", An International Journal, Vol. 29 Issue 2, pp.186-198.

Pines, A. M. and D. Schwartz (2008), "Now you See them, Now you don't: Gender Differences in Entrepreneurship", Journal of Managerial Psychology, Vol. 23, pp. 81132.

Radović-Marković, M. (2009), "Women Entrepreneurs: New Opportunities and Challenges”, Indo-American Books, Delhi.

Radović-Marković, M. (2006), "Perspectives and Possibilities for Small Business Development in Serbia", New Economy Condition, State and Perspectives of Serbian Economy, The scientific gathering at the Institute of the Economic Sciences, Belgrade, pp. 225-231.

Sarri, K., and A. Trihopoulou (2005), "Female Entrepreneurs' Personal Characteristics and Motivation: a Review of the Greek Situation", Women in Management Review, Vol. 20 No. 1, pp. 24-36.

Smith, D. (2010), "The Role of Entrepreneurship in Economic Growth", Undergraduate Economic Review, Vol. 6 No.1, Article 7. 
